\title{
Blog for schoolchildren about people with disabilities: evaluation of learning
}

\author{
Blog para escolares sobre pessoa com deficiência: avaliação da aprendizagem
}

Karine Moreira de Melo ${ }^{1}$, Ana Talyne Pessoa ${ }^{1}$, Cristiana Brasil de Almeida Rebouças ${ }^{1}$, Maguida Gomes da Silva ${ }^{1}$, Paulo César de Almeida ${ }^{2}$, Lorita Marlena Freitag Pagliuca ${ }^{1}$

Objective: to evaluate schoolchildren's knowledge before and after educational intervention using an educational blog about the person with disability. Methods: quantitative study with 74 students participating. Knowledge test was applied. Mean and standard deviation of ages was calculated. McNemar test was used comparing pretest and posttest and Wilcoxon test compared means and medians. Results: after the blog, there was increase of hits in the posttest. Statistical significance was observed in the variables: public and private school $(p=0.001)$; female and male ( $p=0.001)$; groups of 13 to 14 years old $(p=0.001)$ and 15 to 18 years old $(\mathrm{p}=0.001)$. Issues related to visual and auditory impairmentand history and citizenship were less successful in the pretest than the posttest $(\mathrm{p}=0.001)$. Questions about visual and auditory impairment, history and citizenship $(\mathrm{p}=0.001)$ improved the proportion of correct answers after the intervention. Conclusion: educational blog application promoted increased knowledge of schoolchildren about the person with a disability.

Descriptors: Nursing; Educational Technology; Disabled People; Health Promotion.

Objetivo: avaliar conhecimento de escolares antes e após intervenção educativa utilizando blog educativo sobre a pessoa com deficiência. Métodos: estudo quantitativo com participação de 74 estudantes. Aplicado teste de conhecimento. Calculados média e desvio padrão das idades. Utilizou-se teste de McNemar para comparação do pré e pós-teste e teste de Wilcoxon para comparação de médias e medianas. Resultados: após aplicação do blog, verificou-se aumento de acertos no pós-teste. Observou-se significância estatística nas variáveis: escola pública e privada ( $\mathrm{p}=0,001)$; gênero feminino e masculino ( $\mathrm{p}=0,001)$; faixa etária de 13 a 14 anos $(\mathrm{p}=0,001)$ e 15 a 18 anos $(\mathrm{p}=0,001)$. Questões referentes à deficiência visual e auditiva e, história e cidadania tiveram menos acertos no pré-teste $(\mathrm{p}=0,001)$. Questões sobre deficiência visual e auditiva e, história e cidadania $(\mathrm{p}=0,001)$ melhoraram proporções de acertos após intervenção. Conclusão: aplicação de blog educativo promoveu aumento de conhecimento dos escolares sobre a pessoa com deficiência.

Descritores: Enfermagem; Tecnologia Educacional; Pessoas com Deficiência; Promoção da Saúde.

\footnotetext{
${ }^{1}$ Universidade Federal do Ceará. Fortaleza, CE, Brazil.

${ }^{2}$ Universidade Estadual do Ceará. Fortaleza, CE, Brazil. 


\section{Introduction}

In recent years, the dissemination of informatics in education, through educational technologies, has occupied an important place in teaching and learning processes. On the Internet, individuals are confronted with information with agility, speed, without the existence of geographical and temporal barriers. Children and adolescents use the computer as a way of entertainment, learning, and communication ${ }^{(1)}$.

In the health area, professionals have used tools from the digital space as an instrument to convey information about diseases, prevention, education of students, among other subjects. Also, people tend to use these spaces to seek information about diseases, exposing their feelings and experiences with the process of illness, and sharing anguish and suffering with others who are also experiencing something similar. Therefore, web tools, such as blogs, can be used in the development of pedagogical activities, both in the exhibition of information and provided collaborative and interactive spaces between people ${ }^{(2)}$.

The blog is a simplified, easy-to-use and accessible online platform that provides information on the chosen topic. It is understood as an electronic record on the internet. The easiness to perform records for its update is what distinguishes it from a conventional site, making it more dynamic, since its maintenance can be supported by the automatic organization of messages in the system, allowing the incorporation of new texts ${ }^{(3)}$.

This resource is a popular way of communication because it allows for versatility. It is characterized by being a viable tool, easy to execute and with the possibility of interaction that contributes to the discussion of various subjects, especially in the health area ${ }^{(4)}$. In this way, it is important to point out that there are different types of blogs, such as educational blogs. They aim to disseminate scientific, academic and technical content using coherent language to the target audience ${ }^{(5)}$.

The use of blogs is an innovative strategy that allows interacting with adolescents in the school environment, representing a promising place for the practice of actions aimed at health promotion. In this environment, the students spend most of their day, facilitating interactivity with the collective, closer ties, exchange of experiences and sharing of knowledge ${ }^{(6)}$.

People with disabilities find physical and attitudinal barriers to their inclusion in society. It is common to find irregular sidewalks or even with holes, squares with physical and technical barriers, difficulty accessing banks, pharmacies, supermarkets, health services and leisure areas. These obstacles may hinder or prevent people with disabilities from fully enjoying the environment in which they live ${ }^{(7)}$. Providing educational material for school children on this topic is a strategy of information and construction of citizenship to promoting health.

There is evidence that schoolchildren have reduced knowledge about this problem and the use of a labyrinth game was an effective educational strategy to increase knowledge ${ }^{(8)}$. Health education is an important tool for nurses to promote health. Professional can use this strategy with the school public to work and pass on information about people with disabilities. It is also presented as a space for the performance of his practice, evidencing his role as an educator.

The inclusive educational system must be developed since it is indispensable to offer qualified education. It is necessary to recognize the right to accessibility in school as an extension of quality services capable of meeting the specific demands of people with disabilities without masking the limitations they face in their daily lives ${ }^{(9)}$.

In this context, this study becomes relevant, given that the use of educational interventions such as the blog assume a prominent role as support strategies in pedagogic activities, helping the individual to understand the information transmitted to them, because at the moment he knows different subjects, he will be empowering, and becoming more committed to issues inherent to that content.

Creative strategies in health education, such as 
blogs, become interesting resources that can promote learning of different contents that about people with disabilities, minimizing behavioral barriers, favoring inclusion and, consequently, improving the quality of this population group. Faced with this reality, the nurse should develop practices and technologies directed to students about the person with disabilities to generate subsidies to improve their praxis in the health education area.

Faced with the scarcity of studies in the literature about the production of educational interventions aimed at learning about the person with the disability, the following research question emerged: Does the use of technology, in the form of an educational blog, with students contribute to increasing their knowledge about the Disabled person?

Thus, this study aimed to evaluate the knowledge of schoolchildren before and after applying educational blog on the topic of people with disabilities.

\section{Methods}

This is a cross-sectional study based on the application of educational technology in the modality of the blog. The study population included school adolescents enrolled in elementary and high school and who concentrated adolescents in the intermediate phase, that is, in the age group from 15 to 17 years old.

The study was developed in two schools, one private and one public. These institutions were selected intentionally considering the appropriate timetables and places available for the educational intervention. The sample for convenience comprising 74 students, 22 of them being from the ninth grade class of the private school, 27 from the first and 25 from the third year of the public school.

Data collection occurred from August to November 2013, when the principals of the respective institutions indicated one class per school, so there was no exchange of information between students of different classes in the same series. To delimit the sample, inclusion criteria were established: 1 ) to have a minimum age of 13 years old; 2) be regularly enrolled from the ninth grade of elementary school; 3 ) have basic computer skills. The exclusion criteria were: students who did not have time available to participate in educational interventions that would occur outside the class period.

With the authorization of the principals, previous disclosure and invitation to the students were made. Then, an individual meeting of one of the researchers with interested students, in the classroom with the presence of the teacher to be clarified as to the objectives of the study. The students were asked to respond to an interview questionnaire contemplating the sociodemographic characterization, followed by pretest with questions about knowledge concerning the person with a disability.

Then, the students were invited to participate in the educational blog as an educational strategy to broaden their knowledge about the person with a disability. The activity was carried out in the computer lab of the institutions at previously scheduled times. Students received a release password to access the computer.

The students had guidance from one of the researchers to navigate the blog, who was present to clarify doubts. The content was organized into topics, presenting information inherent to the person with physical, visual and auditory deficiency, having space for registering doubts, communication and suggestions.

The information was presented in short texts, curiosities and images to make this tool attractive. On average, the blog application lasted thirty minutes. It should be emphasized that the selection of content was defined after extensive literature review on the subject, mainly among the publications of the Ministry of Health, World Health Organization and scientific articles.

After applying the educational intervention, the students answered the posttest to evaluate the acquired learning. The time interval between the application of the pretest and posttest was one month. Both 
tests were applied by one of the researchers.

The data collection instrument consisted of sociodemographic data and knowledge test (pretest and posttest). Sociodemographic variables were: type of school, female or male gender and age group. The knowledge test was composed of ten questions, three of them low, four medium and three high complexity. The issues addressed in the issues were: history and citizenship of people with disabilities, visual, auditory and physical deficiency.

The questions were distributed at each level of complexity through a draw. Thus, the knowledge test was structured after a draw: three questions of low complexity on visual, auditory and physical deficiency; Four medium complexity questions about history and citizenship, visual, auditory and physical deficiency; And three highly complex questions regarding visual, auditory and physical impairment. It is worth mentioning that the question related to history and citizenship was added to the knowledge test since it was part of the content built on the person with a disability.

The questions were of the multiple-choice type and contained the items "a," "b," "c" and "d." Only one item should be chosen in response to the question. Students were instructed not to leave questions unanswered. The tests were applied in the classroom, individually, with the presence of the educators, through the interaction of one of the researchers with the students. The question in the pretest contained the same complexity and subject matter of the counterpart in the posttest.

Data analysis was performed with a mean and standard deviation of the ages. A McNemar test was used to compare the proportions of before and after the educational intervention and Wilcoxon test for comparison of means and medians before and after the educational activity. The level of significance was set at $5.0 \%$.
The study complied with the formal requirements contained in the national and international regulatory standards for research involving human beings.

\section{Results}

A study was attended by 74 students. Age ranged from 13 to 18 years old with an average of 15 years old and (Standard deviation 1.5). Students aged 15 to 18 (75.7\%), female (56.8\%) predominated.

Table 1 - Mean and median scores according to sociodemographic characteristics. $(n=74)$

\begin{tabular}{|c|c|c|c|c|c|}
\hline \multirow{2}{*}{ Variables } & \multicolumn{2}{|c|}{ Mean } & \multicolumn{2}{|c|}{ Median } & \multirow{2}{*}{$\mathbf{p}^{*}$} \\
\hline & Pretest & Posttest & Pretest & Posttest & \\
\hline \multicolumn{6}{|l|}{ School } \\
\hline Public & 4.98 & 6.57 & 5 & 7 & $<0.001$ \\
\hline Private & 5.50 & 7.68 & 5 & 8 & $<0.001$ \\
\hline \multicolumn{6}{|l|}{ Gender } \\
\hline Female & 5.33 & 7.19 & 5 & 7 & $<0.001$ \\
\hline Male & 4.87 & 6.53 & 5 & 7 & $<0.001$ \\
\hline \multicolumn{6}{|c|}{ Age group (years) } \\
\hline $13-14$ & 5.33 & 7.61 & 5 & 8 & $<0.001$ \\
\hline $15-18$ & 5.07 & 6.67 & 5 & 7 & $<0.001$ \\
\hline
\end{tabular}

Table 1 shows means and medians of correct answers in the pretest and posttest of the educational activity considering sociodemographic characteristics of the students. As for the average number of correct answers, this was higher for private school students in the pretest and posttest, the average of the girls was higher than the boys, between 13 and 14 years old. There was an increase in means and medians in all sociodemographic variables observed. All obtained significant results $(\mathrm{p}<0.001)$. 
Table 2 - Distribution of the number of errors and correct answers according to pretest and posttest by the level of complexity and type of disability. $(n=74)$

\begin{tabular}{|c|c|c|c|c|c|}
\hline \multirow[b]{2}{*}{ Variables } & \multicolumn{2}{|c|}{ Pretest } & \multicolumn{2}{|c|}{ Posttest } & \multirow[b]{2}{*}{$\mathbf{P}^{*}$} \\
\hline & $\begin{array}{l}\text { Error } \\
\text { n (\%) }\end{array}$ & $\begin{array}{l}\text { Correct } \\
\text { n (\%) }\end{array}$ & $\begin{array}{l}\text { Error } \\
\text { n (\%) }\end{array}$ & $\begin{array}{l}\text { Correct } \\
\text { n (\%) }\end{array}$ & \\
\hline \multicolumn{6}{|l|}{ Low complexity } \\
\hline Visual impairment & 68 (91.9) & $6(8.1)$ & $50(67.6)$ & $24(32.4)$ & $<0.001$ \\
\hline Hearing deficiency & $38(51.4)$ & $36(48.6)$ & $13(17.6)$ & $61(82.4)$ & $<0.001$ \\
\hline Physical disability & $2(2.7)$ & 72 (97.3) & $20(27.0)$ & $54(73.0)$ & $<0.001$ \\
\hline \multicolumn{6}{|l|}{ Medium complexity } \\
\hline History and citizenship & 65 (87.8) & $9(12.2)$ & $7(9.5)$ & $67(90.5)$ & $<0.001$ \\
\hline Visual impairment & $28(37.8)$ & $46(62.2)$ & $4(5.4)$ & $70(94.6)$ & $<0.001$ \\
\hline Hearing deficiency & $10(13.5)$ & $64(86.5)$ & $36(48.6)$ & $38(51.4)$ & 0.002 \\
\hline Physical disability & $69(93.2)$ & $5(6.8)$ & $62(83.8)$ & $12(16.2)$ & 1.000 \\
\hline \multicolumn{6}{|l|}{ High complexity } \\
\hline Visual impairment & $23(31.1)$ & $51(68.9)$ & $11(14.9)$ & $63(85.1)$ & 0.068 \\
\hline Hearing deficiency & $38(51.4)$ & $36(48.6)$ & $14(18.9)$ & $60(81.1)$ & $<0.001$ \\
\hline Physical disability & 19 (25.7) & $55(74.3)$ & 12 (16.2) & $62(83.8)$ & 0.542 \\
\hline
\end{tabular}

Table 2 summarizes the result of errors and correct answers regarding the questions applied in the pretest and posttest to the students. Significance was obtained, with an increase in the percentage of correct answers, in five questions, $\mathrm{p}<0.001$, two of low complexity, on visual and auditory deficiency; Two of medium complexity on history and citizenship and visual impairment; And a highly complex hearing impairment.

\section{Discussion}

Students from the private school presented more previous knowledge about the subject, with a higher previous and subsequent mean of correct answers. Corroborating with research that evaluated students' knowledge about this subject, through the use of labyrinth game, private school students presented higher prior knowledge, with a higher average and median scores in the pretest. However, the public school showed more learning after the application of the game ${ }^{(8)}$. Discussions about this audience can be enriched with the use of educational technologies, facilitating an understanding of this theme by awakening curiosities, promoting dialogue and experiences with the goal of minimizing barriers.

The use of educational strategies can enrich the pedagogical activities since they are facilitating resources in the process of teaching and learning. The search for new methodologies in health has grown significantly in the last decades ${ }^{(10)}$.

Regarding gender, the results revealed that girls and boys presented the same median of correct answers in the pretest and posttest, and there were no significant differences in the results. In this way, students of both genders demonstrated similar performance regarding the knowledge test. A different result is pointed out in research with high school students about sex education, which compared pretest and posttest students' performance after the educational intervention, showing a significant difference in performance among female gender tests ${ }^{(11)}$.

The age group of 13 to 14 years old presented a superior performance than the students of 15 to 18 years old, evidencing that younger students obtained greater learning. The explanation for this result may be related to the fact that more and more new generations are willing to interact with technological innovations. These means enable young people to acquire information, combining with fun. They work as a complementary learning activity, as a resource for introducing new knowledge, the motivation for the learner or information ${ }^{(12)}$.

In this study, the posttest when compared to the pretest, indicated a higher percentage of correct answers, evidencing that the application of educational intervention, through the use of a blog, can be an ambiance to promote learning. A similar result is observed in research that used educational technology for adolescents, showing significant changes in the learning process and understanding about the topic 
addressed in the application of technology ${ }^{(13)}$. These technological resources can be used as spaces for the development of skills directed to different contexts.

Analyzing the students' answers for the pretest and the posttest, according to the level of complexity of the questions, it was verified that the most consolidated knowledge among them was about hearing impairment. Distinctly, learning of adolescent students about the person with disabilities, using educational technology in the board game, obtained better results in the theme involving visual deficiency ${ }^{(14)}$. Thus, results show that adolescents have little mastery over the subject.

The population needs to be able to interact with the disabled people. For adolescents to develop skills and learn to behave in the face of a situation involving this population group, it is necessary to sensitize them from the school to the construction of knowledge about this population. The school environment represents a practical and efficient environment for transmitting information to young people on issues related to the context of the disabled person.

In the questions of low complexity, the questions about visual and auditory impairmentindicated significant results. In the question about visual impairment, the types of blindness (congenital, acquired, functional and low vision) was addressed in the pretest. Its numerical correspondent addressed the posttest on ocular trauma. The large percentage of errors in knowledge demonstrates that students did not know the difference between types of blindness. However, in the posttest, most of the students demonstrated learning about possible causes of ocular trauma: traffic accidents, physical aggressions, and foreign body.

From the findings, we observed that the theme about the types of blindness is little known by the students. This result may be related to the lack of information and actions specifically focused on the person with disabilities in the school environment. This place should ensure that learners learn to relate to other subjects. Behaviors, attitudes, and learning are stron- gly marked by the quality of relationships that can be established ${ }^{(15)}$.

Teaching about eye trauma is important, as adolescents are vulnerable to this type of event. At this stage of life, they assume various risk behaviors, such as physical aggressions, car accidents they are not prepared, which is often due to the anxiety of living in a fast and intense way, which is why they do not reflect on their attitudes ${ }^{(16)}$. In this way, sharing information is necessary for the prevention of health problems of these subjects.

Also in the questions of low complexity, the question of hearing impairmentaddressed in the pretest about the Brazilian Language of Signals. A large number of errors in the pretest indicated that the students did not know that this was the official language of the hearing impaired person, being used by most deaf people to facilitate communication. In the posttest, students were right about the factors that can cause deafness.

In adolescence, there are also factors that can cause hearing problems resulting in deafness. When a subject is repeatedly exposed to loud noise, there is a risk of irreversible hearing loss. Therefore, an important way of sensitizing adolescents to the prevention of deafness can be through health education practices, which appear as a possibility to provide subsidies to educate and care, promoting health and quality of life $^{(17) .}$

In the subjects of medium complexity, the students presented a higher level of knowledge in the posttest in the subjects about history and citizenship and visual deficiency. In the questions on history and citizenship, the periods of exclusion, segregation, integration and inclusion were discussed, in which society must know how to live with these people. It is important to talk about the history of people with disabilities, disseminating information, building a concept of citizenship.

When addressing the issue of people with disabilities, it is necessary for the target public to be aware of the attitudinal and physical barriers that prevent 
the effective inclusion of the disabled in society ${ }^{(18)}$. In the issue of medium complexity, on the visual impairment, it was questioned how to help the blind person crossing the street, there was a significant number of correct answers showing that the adolescents knew the problem.

High complexity questions obtained significant answers related to hearing impairment. In the pretest, the diseases that cause deafness to the newborn were discussed, and in the posttest, about risks that may result in deafness. The high number of errors in the pretest showed that the students did not have mastery of the content. After the educational intervention, there was learning. Therefore, reflecting and expanding studies on this theme is necessary to generate new knowledge that helps improve the quality of care, improving public policies, accessing and ensuring comprehensive health care for these people ${ }^{(19)}$.

The role of the nurse in the development of educational interventions is evidenced in the position of an educator. This practice is not only a sharing of information but a transforming educational practice that allows individuals to reflect and decide attitu$\operatorname{des}^{(20)}$. It is important to develop educational actions favoring nursing care for the health of schoolchildren.

The main limitations of the study are because there is a reduced sample and a shortage of similar articles in the national and international literature to compare the results found. Therefore, it is suggested that educational blog is applied again in larger and diversified samples, for better interpretations.

\section{Conclusion}

A study showed that the average correctness was higher for pretest and posttest to private school students, girls, between 13 and 14 years old. Low and medium-complexity questions obtained twice as many successful hits as high-complexity questions.

The educational blog application contributes to the apprehension of the knowledge related to the content addressed. That is, when applied by nurses, an educational blog can broaden and strengthen the knowledge of schoolchildren on the issue of people with disabilities. In this study, regarding the level of complexity of the questions, the best result was with the theme related to hearing impairment.

\section{Acknowledgment}

To the Conselho Nacional de Desenvolvimento Científico e Tecnológico for the financial support, through the scholarship of Scientific Initiation.

\section{Collaborations}

Melo KM contributed to the design, planning, analysis and writing of the article. Pessoa AT, Rebouças CBA and Silva MG contributed to the writing of the article. Almeida PC contributed to the analysis and interpretation of the data. Pagliuca LMF contributed in the critical review of the content and approval of the final version to be published.

\section{References}

1. Araújo PKH, Pillotto SSD. As redes sociais como possibilidade de aprendizado no currículo e nas construções identitárias no contexto da educação infantil. Curríc Fronteiras. 2013; 13(1):20-34.

2. Cruz DI, Paulo RRD, Dias WS, Martins VF, Gandolfi PE. O uso das mídias digitais na educação em saúde. Cad FUCAMP. 2011; 10(13):130-42.

3. Berti FR, Souza DOG. Comunicação científica em blogs: convergências e divergências nas visões do pesquisador e da sociedade. Rev AMRIGS. 2012; 56(2):133-40.

4. Valli GP, Cogo AL. Blogs escolares sobre sexualidade: estudo exploratório documental. Rev Gaúcha Enferm. 2013; 34(3):31-7.

5. Mestre-Mestre EM. La implicatura en los blogs educativos. Una aproximación pragmática. Tic Rev D'innovació Educ [Internet]. 2015 [citado 2016 nov 12]; 15:90-6. Disponível em: http://www. redalyc.org/articulo.oa?id=349543461012 
6. Faial LCM, Silva RMCR, Pereira ER, Refrande SM, Souza LMC, Faial CSG. A escola como campo de promoção à saúde na adolescência: revisão literária. Rev Pró-Univer SUS. 2016; 7(2):22-9.

7. Freire Júnior RC, Arêas GPT, Arêas FZS, Barbosa LG. Estudo da acessibilidade de idosos ao centro da cidade de Caratinga, MG. Rev Bras Geriatr Gerontol. 2013; 16(3):541-58.

8. Silva JM, Pagliuca LMF, Carvalho AT, Oliveira MG, Almeida PC. Conhecimento de escolares acerca de pessoa com deficiência: jogo de labirinto na promoção da saúde. Rev Enferm UERJ. 2015; 23(2):254-9.

9. Carvalho MAAS, Durand VCR, Melo PD. A acessibilidade na escola como direito a educação: o que falam os estudos empíricos nacionais. Rev Principia Divulg Cient Tecnol IFPB. 2016; 29(s/ n):61-8.

10. Medeiros MJA, Santos JO. O jogo e sua utilização psicopedagógica na educação infantil. Rev Bras Educ Saúde. 2016; 6(1):36-41.

11. Stradiottia KM, Alves AA, Castro DCKM, Camillo FG, Pancini ID, Silva LFG, et al. Percepção de estudantes do ensino médio quanto a palestras sobre educação sexual em campo grande. UNOPAR Cient Ciênc Human Educ. 2015; 16(esp.):423-27.

12. Barbosa Neto JF, Fonseca FS. Jogos educativos em dispositivos móveis como auxílio ao ensino da matemática. Rev Novas Tecnol Educ [Internet]. 2013 [citado 2017 jan. 10]; 11(1). Disponível em: http://seer.ufrgs.br/index.php/renote/article/ view/41623/2640

13. Lemos ICS, Miranda MLF, Matias LVR, Lédio MF, Alves ACP, Masques SF. Tecnologia educativa para trabalhar a sexualidade de adolescentes no contexto escolar. Rev Interd. 2015; 8(3):110-8.
14. Vasconcelos FKA, Pagliuca LMF, Carvalho AT, Oliveira MG, Almeida PC. The learning of adolescent students about the disabled person using board game. Open J Nurs. 2015; 5(3):17380.

15. Miguel IS, Santos MJ, Galinha S. A promoção e o desenvolvimento de competências pessoais e sociais no 9o ano de escolaridade - resultados da intervenção do projeto oficina da prevenção. Rev UilPS [Internet]. 2016 [citado 2017 jan. 10]; 4(2). Disponível em: http://revistas.rcaap.pt/uiips/ article/view/9918

16. Carneiro RF, Silva NC, Alves TA, Albuquerque DO, Brito DC, Oliveira LL. Educação sexual na adolescência: uma abordagem no contexto escolar. SANARE. 2015; 14(1):104-8.

17. Barbosa EF, Moura DG. Metodologias ativas de aprendizagem na educação profissional e tecnológica. Tec Senac. 2013; 39(2):48-67.

18. Martins LMSM, Silva GS. Trajetória acadêmica de uma estudante com deficiência visual no ensino superior. Rev Educ Questão. 2016; 54(41):251-74.

19. Pessalacia JDR, Ribeiro IKS, Rates CMP, Azevedo C, Braga PP. Experiências de acesso a serviços primários de saúde por pessoas com Síndrome de Down. Rev Enferm Cent O Min. 2015; 5(3):175267.

20. Martins MC, Ferreira AMV, Nascimento LA, Aires JS, Almeida PC, Ximenes LB. Influence of an educational strategy to promote the use of regional food. Rev Eletr Enf [Internet]. 2015 [cited 2017 Jan. 09]; 16(2):242-9. Available from: http://www.periodicos.ufc.br/index.php/rene/ article/view/2719/2103. 